\begin{tabular}{cc|c}
\hline Tar. Bil. Der. & Tarım Bilimleri Dergisi & Journal of Agricultural Sciences \\
& $\begin{array}{c}\text { Dergi web sayfası: } \\
\text { www.agri.ankara.edu.tr/dergi }\end{array}$ & Journal homepage: \\
& www.agri.ankara.edu.tr/journal
\end{tabular}

\title{
A Visual Assessment of Roadside Poplar Plantings in Turkey
}

\author{
Engin EROĞLU ${ }^{\mathrm{a}}$, Cengiz ACAR
}

${ }^{a}$ Duzce University, Faculty of Forestry, Department of Landscape Architecture, Düzce, TURKEY

${ }^{b}$ Karadeniz Technical University, Faculty of Forestry, Department of Landscape Architecture, Trabzon, TURKEY

\section{ARTICLE INFO}

Research Article

DOI: $10.15832 /$ ankutbd.446436

Corresponding Author: Engin EROĞLU, E-mail: engineroglu@duzce.edu.tr, Tel: +90 (533) 6488978

Received: 18 March 2015, Received in Revised Form: 07 February 2017, Accepted: 08 February 2017

\begin{abstract}
Roadside plantings along urban and rural road corridors are designed to create visual effects as well as to provide functional benefits such as shading, screening or routing. Considering their potential for daily public use, roads and road corridors, as significant visual impact centers, can attract people's attention and affect their points of view. Poplar species, which grow rapidly and easily along road corridors and can adapt to different ecological conditions swiftly, are used widely in both urban and rural landscapes in Turkey. The main objective of this study was to determine the visual structures dependent on the road-plant relationships of the poplar compositions that play an important role in shaping the roadside landscapes. For this purpose, compositions of poplar trees in selected urban and rural road corridors throughout Turkey were photographed and visual analysis techniques (VATs) were applied to determine visual preferences. Participants $(\mathrm{n}=35)$ were shown 30 photographs, selected from the nearly 1000 taken, of road corridor poplar plantings and their evaluations were recorded in a questionnaire. In this survey, the people were requested to evaluate their appreciation levels towards the plantings as well as to express their other visual preferences and to assess visual quality. In addition, the association of all these evaluations with the demographic characteristics of the participants were determined. A correlation analysis was then performed to identify the relationships among all the visual assessments and a cluster analysis was conducted according to the visual status of the photographs in order to determine their groups. In the results of the study, the poplar trees, either individually or in the form of compositions, were reported to have a significant visual diversity. Moreover, the cluster analysis found the resulting three groups to be associated with leaf density, seasonal conditions and the trees as individuals or in groups. The seasonal variation factor in particular was shown to be visually effective in the poplar compositions. It was determined that visual perception of the poplar plantations differed in accordance with the demographic differences. This work established that poplar plantations as single trees or in groups and their proximity to the road altered visual preferences, and consequently, some suggestions were made concerning the use of poplars in roadside landscape planning.
\end{abstract}

Keywords: Poplar plantings; Plant compositions; Rural and urban roadside environments; Roadside vegetation; Visual assessment techniques (VATs)

\section{Türkiye'deki Yol Kenarı Kavak Bitkilendirmelerinin Görsel Değerlendirmesi}

\section{ESER BILGİII}

Araştırma Makalesi

Sorumlu Yazar: Engin EROĞLU, E-posta: engineroglu@duzce.edu.tr, Tel: +90 (533) 6488978

Geliş Tarihi: 18 Mart 2015, Düzeltmelerin Gelişi: 07 Şubat 2017, Kabul: 08 Şubat 2017 


\section{ÖZET}

Kentsel ve kırsal yol koridorları bitkilendirmeleri hem görsel etkiler oluşturmak hem de gölge, perdeleme ve yönlendirme oluşturma gibi işlevlerle gerçekleştirilmektedir. Kullanım potansiyeli dikkate alındığında yol ve yol koridorları günlük yaşamında önemli bir görsel etki merkezi ve manzara noktası olarak da dikkat çekmektedir. Türkiye'de yol koridorlarında kolay yetiştirilme, hızlı büyüme, farklı ekolojik koşullara hızlıca adapte olabilme özellikleri ile kavak türleri hem kentsel hem de kırsal peyzajlarda yaygın bir şekilde kullanılmaktadır. Çalışmanın temel amacı kırsal ve kentsel yol kenarı peyzajlarının şekillenmesinde önemli bir rol oynayan kavak kompozisyonlarının yol-bitki ilişkilerine bağlı görsel yapılarını belirlemektir. Bu amaçla, Türkiye'deki bazı kentsel ve kırsal yol koridorlarındaki kavak kompozisyonları fotoğraflanmış ve görsel tercihlerinin belirlenmesinde görsel değerlendirme teknikleri (GDT) uygulanmıştır. Yol koridoru boyunca kavak bitkilendirmelerinin görsel değerlendirme teknikleri içerisinde alandan çekilen fotoğrafların değerlendirmeleri için anket çalışması gerçekleştirilmiştir. Alandan çekilen yaklaşık 1000 fotoğraf içerisinden seçilen 30 fotoğraf toplam 35 katılımcıya değerlendirtilmiştir. Bu anket çalışmasında kişilerin bitkilendirmelere yönelik beğeni düzeylerinin yanı sıra diğer görsel tercihleri ve görsel kaliteye yönelik değerlendirmeleri istenmiştir. Tüm bu değerlendirmeler kişilerin demografik yapıları ile de ilişkilendirilmiştir. Ayrıca tüm görsel değerlendirmelerin aralarındaki ilişkilerin belirlenmesinde korelasyon analizi ve fotoğrafların görsel durumlarına göre oluşturdukları grupların belirlenmesinde kümeleme analizi yapılmıştır. Çalışmanın sonucunda, tek tek ya da kompozisyonlar halinde bulunan kavak ağaçları önemli bir görsel çeşitliliğe sahip oldukları belirlenmiştir. Kümeleme analizinde ortaya çıkan sonuçlarda da ortaya çıkan üç grup, bitkilerdeki yaprak yoğunluğu, mevsimsel durum ve bitkilerin tek ya da gruplar halinde olmaları ile ilişkilidir. Özellikle, mevsimsel değişim kavak kompozisyonlarının görsel tercihlerinde etkili olduğu görülmüştür. Demografik farklılıklara göre kavak bitkilendirmelerinin görsel algısında da değişimlerin olduğu belirlenmiştir. Bitkilendirmelerin tek tek ya da gruplar halinde olması, bitkilerin yola olan yakınlık ve uzaklıklarının görsel tercihleri değiştirdiğinin belirlendiği bu çalışmanın sonucunda yol kenarı peyzaj planlamalarında kavakların kullanımına yönelik öneriler getirilmiştir.

Anahtar Kelimeler: Kavak bitkilendirmeleri; Bitki kompozisyonlar1; Kentsel ve kırsal yol kenarlar1; Yol kenarı vejetasyonu; Görsel değerlendirme teknikleri (GDT)

(C) Ankara Üniversitesi Ziraat Fakültesi

\section{Introduction}

Roadside corridors are extremely important ecologically in terms of both human activity and vehicle movement. When considered in this context, roadside tree populations, both natural and planted, have emerged as an important subject of study, especially the poplar species, which are capable of providing a link between rural and urban settings.

Trees are closest and most useful to people when they are close to the road environment, especially in urban areas. Alongside the ecological approach, there are other elements important for roadside corridor plantings, including the environmental aesthetics and visual beauty considerations discussed in their visual evaluation (Akbar et al 2003). It has been demonstrated that the visual quality of the landscape aesthetics affects motorists and their operation of vehicles (Fathi \& Masnavi 2014). Plants are the most important element contributing to visual quality along the highway corridor. The presence of plants on the road and in the immediate vicinity of the road was found to be preferable to unnatural elements such as lighting, litter, and barriers (Froment \& Domon 2006). Likewise, for road users, groups of trees along the corridor were preferred to other plant groups (Todorova et al 2004; Spooner \& Lisa 2009; Weber et al 2014).

The poplar is easily adapted to both rural and urban settings and is often preferred because of its rapid growth. Poplars have a place in many areas of landscape planning and design work, including amenity plantings in parks, along roads and in residential gardens, public areas and green spaces, as well as in landscape restoration work and for wind screens and noise reduction (Çepel 1998; Görcelioğlu 2002; Yavuzşefik \& Uzun 2005; Dirik 2008). 
In Turkey, the poplar (Populus L.) is one of the plant species used in urban and roadside tree plantings. Populus L. in the family Salicaceae has six native taxa in Turkey (Yaltırı 1993). The poplar taxa are largely foreign to the culture in question. In particular, Populus nigra L. and its hybrids are the most widely grown poplar in and around cities (Ürgenç 1998). However, problems concerning the use of poplar trees in the city have sometimes arisen. Most of these debates remain in a narrow framework and deal with allergy issues caused by spring pollen and the cottony seeds. Both the positive and the adverse effects on health resulting from the presence of poplar species in urban environments must be evaluated, and the versatility of a landscape dominated by poplar must at the same time be considered.

On the other hand, fast-growing species like poplar and eucalyptus planted on the side of the road are responsible for causing cracks in asphalt pavements because the roots have developed close to the soil surface. Next to buildings, these trees can damage foundations. Therefore, fast-growing species should not be planted along narrow roads or next to buildings (Trowbridge \& Bassuk 2004; Yılmaz 2008; Avşar \& Ok 2010).

A number of studies have visually evaluated roadside and corridor plantings and reported elements of the visual preferences and values of effective visual quality such as plant species, plant age and size, proximity to the road, diversity and seasonal changes (Mader \& Neubert-Mader 2004; Wolf 2006; Bulut \& Yilmaz 2008; Eroğlu et al 2012; Fathi \& Masnavi 2014; Demir \& Eroğlu 2015). Hence, the present study aimed to determine the type of poplar plantations most visually preferred alongside roads in Turkey, especially in Anatolia. The parameters subjected to evaluation included visual preference and visual quality, potential of seasonal variation and proximity to the road.

Thus, the basic purposes of the study were to determine the visual value of roadside poplar plantings in Turkey and to utilize this research to design roadside landscapes, to determine the visual status of roadside poplar plantings, to compare visual preferences and visual values of roadside poplar plantings, to identify which visual descriptor groups affect visual preferences of roadside poplar plantings and to assess which landscapes and visual components are important for determining the visual effects of roadside poplar stands.

\section{Material and Methods}

\subsection{Study areas}

In selecting the study areas, the geographical region in Turkey of the roadside poplar planting sites was not taken into account. The most important reason for choosing these areas for the study was that they can represent different climatic conditions in Turkey, and poplar stands are most frequently found along the roadsides. Consequently, the research was carried out using roadside poplar plantings in the vicinity of the Turkish cities of Samsun, Antalya, Erzurum, Karabük, Ankara, Isparta and Kastamonu from February to September 2012. While Samsun and Antalya are coastal cities, Ankara, Isparta, Kastamonu, Karabük and Erzurum are located in the interior regions of Turkey (Figure 1). In selection of the road corridors that make up the research areas, rather than the systematic sampling approach, the conscious or random sampling of road corridors having poplar plantings was adopted. The dependent variables were kept simple and included topography, weather or road geometry. For this research, only the road-plant relationship was important.

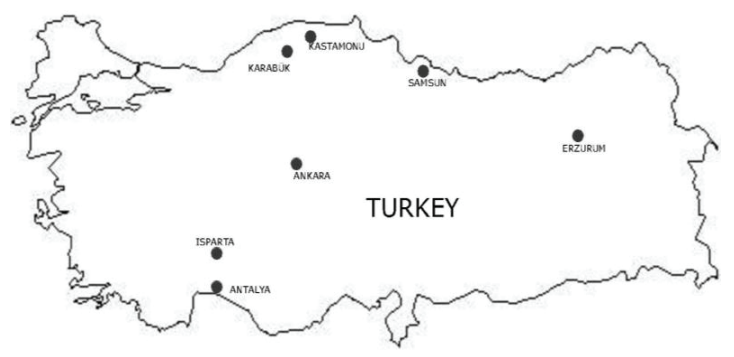

Figure 1- Roadside poplar planting sites selected for the study 


\subsection{Methods}

In the research, an analytical approach was adopted in order to determine the visual structure of the road corridor and to attempt to explain the road corridorplant relationship. Many visual assessment techniques (VATs) for determining the visual value of a landscape are found in the literature, and include surveys, in situ observation, creation of observation maps and on-site assessment by participants. In this study, the survey approach was chosen for the visual evaluation of the study areas. For visual assessment especially, most studies are carried out using this method (Akbar et al 2003; Acar et al 2006; Demir \& Eroğlu 2015)

\subsubsection{Landscape photographs and participant selection}

Many approaches have been employed for visual landscape assessment. The use of visuals depicting the area is a frequently referenced method in the determination of the visual value and quality of a landscape (Clay \& Daniel 2000; Müderrisoğlu \& Eroğlu 2006; Acar et al 2008; Eroğlu \& Acar 2011; Eroğlu et al 2012; Acar et al 2013).

In this study, the visual landscape assessment of roadside plantings was accomplished by photographic analysis. Clay \& Smidt (2004) examined the reliability of using color photos and slides to elucidate visual differences of landscape conditions and for the development of quantitative relationships between photo-based assessment and landscape attributes (Daniel \& Vining 1983). The present study investigated different roadside poplar groups by representing the study sites in photographs. This procedure was selected in order to determine the roadside corridor structures and the visual qualities of the poplar plantings. The photos were intended to capture the most relevant features within each selected corridor.

In this study, a large number of landscape photographs were taken of poplar plantings along the roadsides in a number of sites near cities throughout Turkey using the Canon EOS 500D equipped with an $18-55 \mathrm{~mm}$ standard lens. The photos were taken between 10.00 a.m. and 2.30 p.m. The photography techniques implemented in this study correspond to those in the studies of other researchers (Clay $\&$ Smidt 2004; Acar et al 2006). Between 50 and 100 photos of each corridor were taken and a set of nearly 1000 samples in total was created. The 30 test photos were evaluated and selected by Turkish $\mathrm{BSc}, \mathrm{MSc}$ and $\mathrm{PhD}$ landscape architects. In the study, a participatory survey approach was adopted for the photo evaluations. Rather than different user groups in the vicinity of the road corridor, a single user group was considered for evaluating several corridors (Acar et al 2006).

In order to determine whether the selected photographs were grouped according to the similarity of their visual landscape features, visual perception variables (natural, varied, impressive, eye-catching, harmonious, interesting and exciting) were used.

\subsubsection{Survey of visual assessment}

The visual values (VVs) of preferences for the roadside poplar plantings were rated using a participatory approach (Brown \& Daniel 1990; Ode et al 2009). The 35 participants (90\% community contribution level, 95\% confidence interval and 85\% confidence level) (Kalıpsız 1981) were randomly selected and consisted of 20 men and 15 women between the ages of 22 and 50 working in several Turkish universities as academic faculty. In order to ascertain whether any relation existed between visual preferences and participant demographic features, in the correlation analysis, age, gender, work and education were used as demographic features along with the visual values. The participants were shown the 30 test slides from the study sites and asked to rate each slide on a 7-point scale: $-3(1),-2(2),-1(3)$, $0(4), 1(5), 2(6), 3(7)$, where a 1 indicated a very low visual value and a 7 indicated a very high one. Aided by the pictures, the visual preferences were assessed according to the semantic differential scale (SDS) proposed by Osgood et al (1957). This scale is used in the subject field of landscape and environmental psychology research and is carried out with pairs of 5 or 7 items (Özgen 1984; Acar \& Gülez 2002).

In this study, correlations $(-1 \leq \mathrm{r}<-0.9$-strong $(-)$, $-0.9 \leq \mathrm{r}<-0.5$-medium $(-),-0.5 \leq \mathrm{r}<0$-weak $(-), 0.9<\mathrm{r} \leq 1$ - 
strong $(+), \quad 0.5<\mathrm{r} \leq 0.9$-medium $(+), \quad 0<\mathrm{r} \leq 05$-weak $(+)$ and correlations significant at the 0.01 and 0.05 levels) between the rating levels of visual values and the assessment of semantic descriptors assumed some descriptors to be unique or independent information about preference for a scenic composition. The participants were surveyed using the semantic descriptors correlated with the visual values. In this way, the 30 test slides were presented and the participants used nine the descriptor variables along with visual preference and visual quality (Table 1).

\subsubsection{Statistical analysis}

A data matrix was completed in Excel, including VV preference scores, VV aims, semantic descriptors, landscape characteristics of each slide and participants' demographics. The data were analyzed using the SPSS (Statistical Package for Social Science) 16.0.

Quantitative and qualitative analytical techniques were used to analyze and interpret the data set extracted from the preferences scale system in the Excel Program; the data matrix was obtained by including the values of the preferences. Based on mean assessed values calculated from all values, the visual values were given to illustrate general patterns of planting preferences. The data matrix was subjected to basic descriptive statistics, analysis of variance and cluster analysis. In order to describe the explanatory variables of the corridor landscapes, a correlation analysis of the scale variables was carried out.

In the study, to differentiate the road corridors poplar views from each other, cluster analysis in SPSS 16.0 software was applied to determine common affairs point groupings. How the formation of groups were linked to the corridor-plant relationship and the possible significance were confirmed by cluster analysis. Cluster analysis was used to test whether poplar plantation corridors were connected or whether they had randomly formed a typology.

Of the hierarchical clustering techniques, the variance technique (Ward's method) was designated. This technique utilizes the total squared deviation and is based on the average distance from the observations found in the same cluster.

Cluster analysis is one of the multivariate analysis techniques and takes into account the basic features of an object or group of individuals and put them into groups. In other words, with cluster analysis, ungrouped data are grouped according to their similarities in order to provide cumulative information to researchers. Cluster analysis, by calculating the values of all the measured variables of the units seen in the research, groups the units

Table 1- Visual characteristics selected for study

\begin{tabular}{ll}
\hline Visual attributes & \multicolumn{1}{c}{ General definitions } \\
\hline Natural & - Directly correlated with landscape preferences. Nature is often appreciated more than man-made \\
Varied & landscapes. \\
Impressive & - Related to complexity, and defined as "the diversity and richness of a landscape and its features." \\
& - Related to the perceptual level of admiration shown to a landscape. The appreciation level of a \\
Eye-catching & - Refers to landscapes that completely affect the perception level. Unremarkable landscapes do not \\
& convey a perceptual sense. \\
Harmonious & - Refers to all the elements of a landscape forming a whole, or also to each element being com- \\
& patible with the others. It is a perceptual component that is more effective in directing the visual \\
& preferences. \\
Interesting & - Can refer to a landscape or composition found directly interesting, or else to the appreciation of \\
& the landscape. From time to time, the "interesting" designation can also show an inverse relation- \\
Exciting & ship with appreciation. \\
& - Refers unforgettable landscapes that are the most easily perceived by people. They are character- \\
& ized by a high level of appreciation.
\end{tabular}

Tarım Bilimleri Dergisi - Journal of Agricultural Sciences

$24(2018) 185-198$ 
resembling each other in the same cluster. The analysis focuses on emerging groups and clusters; the obtained clusters are homogeneous in themselves, while being heterogeneous in relation to each other (Kalayc1 2010). Thus, cluster analysis is used to classify units or objects according to their basic features (Everitt et al 2001; Abonyi \& Feil 2007).

Following this hierarchical cluster analysis, discriminant analysis was employed in order to test whether the levels of separation were sufficient. Discriminant or separation analysis is a multivariate statistical technique for dividing two or more previously classified groups. Observations taken from outside a group indicate the group to which it can be assigned. Cluster analysis, in statistical terms, creates groups which differ from each other. It does not state what criteria will be used to classify those members joining the groups later. Discriminant analysis learns how the cluster analysis units are grouped and can easily classify other units that would be joining the groups.

\section{Results}

\subsection{Visual preferences}

When the arithmetic mean of the images was calculated (Figure 2 and Table 2), the photos

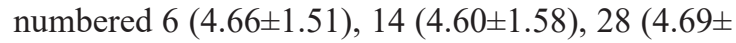
$1.71), 29(4.94 \pm 1.53)$ and $30(4.57 \pm 1.40)$ had the highest values (Figure 3), while the photos numbered $2(3.28 \pm 1.60), 12(3.26 \pm 1.58), 15(3.09 \pm$ 1.96), $20(3.00 \pm 1.70)$ and $21(3.20 \pm 1.53)$ had the lowest (Figure 4). The photos and their descriptor groups were calculated according to their frequency. Accordingly, the most varied was photo number 29 , the most impressive was 14 and the most eyecatching was 6 , while the most harmonious, natural, interesting and exciting photo was number 8 .

According to the results of the correlation analysis, all the semantic descriptor groups were influential in determining visual preferences (Table 3). As shown by the analysis, interesting and exciting were the visual preference pair determined to be the most effective at $\mathrm{P}=0.588$ and 0.01 significance levels, respectively. Roadside poplar plantings identified as exciting exhibited an effective visual preference.

As shown in Table 3, natural and varied had a positive relationship with visual preferences, while they showed no relation to visual quality levels. Overall, visual preferences related positively to natural, varied, impressive, eye-catching, harmonious, interesting and exciting, while visual quality levels related negatively to those same descriptors.

\subsection{Effects of the socio-demographic characteristics of respondents}

The demographics of the participants were examined when determining the visual preferences.

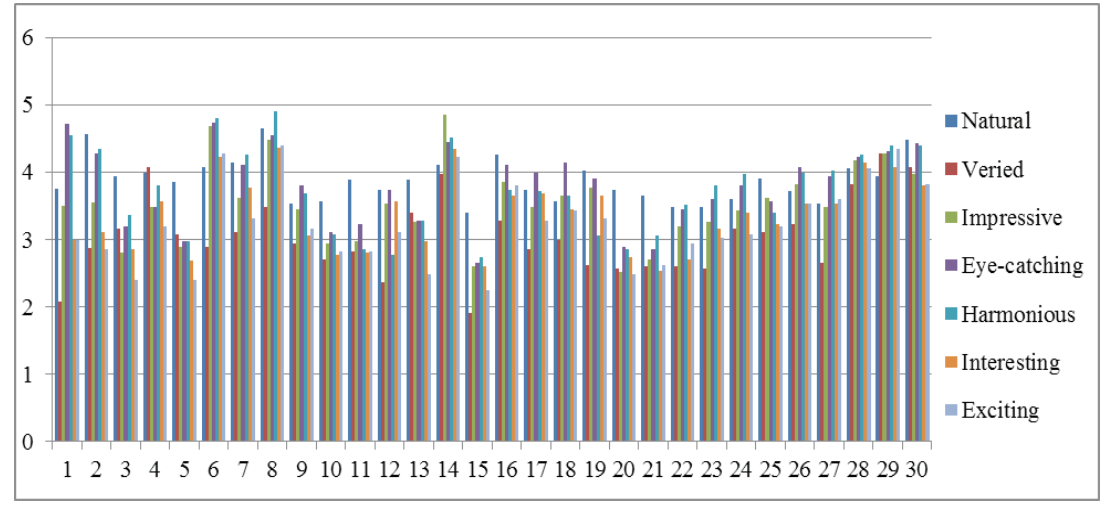

Figure 2- Relationship between images and semantic adjectives 
Table 2- Arithmetic means of semantic meaning of photos

\begin{tabular}{|c|c|c|c|c|c|c|c|c|}
\hline $\begin{array}{c}\text { Photo } \\
\text { numbers }\end{array}$ & Natural & Varied & Impressive & Eye-Catching & Harmonious & Interesting & Exciting & $\begin{array}{l}\text { Total } \\
\text { mean }\end{array}$ \\
\hline 1 & 3.75 & 2.08 & 3.50 & 4.72 & 4.56 & 3.00 & 3.00 & 3.52 \\
\hline 2 & 4.56 & 2.88 & 3.55 & 4.28 & 4.34 & 3.11 & 2.86 & 3.65 \\
\hline 3 & 3.94 & 3.17 & 2.80 & 3.20 & 3.37 & 2.86 & 2.40 & 3.11 \\
\hline 4 & 4.00 & 4.09 & 3.49 & 3.49 & 3.80 & 3.57 & 3.20 & 3.66 \\
\hline 5 & 3.86 & 3.09 & 2.89 & 2.97 & 2.97 & 2.69 & 2.40 & 2.98 \\
\hline 6 & 4.09 & 2.89 & 4.69 & 4.74 & 4.80 & 4.23 & 4.29 & 4.24 \\
\hline 7 & 4.14 & 3.11 & 3.63 & 4.11 & 4.26 & 3.77 & 3.31 & 3.76 \\
\hline 8 & 4.66 & 3.49 & 4.49 & 4.54 & 4.91 & 4.37 & 4.40 & 4.41 \\
\hline 9 & 3.54 & 2.94 & 3.46 & 3.80 & 3.69 & 3.06 & 3.17 & 3.38 \\
\hline 10 & 3.57 & 2.71 & 2.94 & 3.11 & 3.09 & 2.77 & 2.83 & 3.00 \\
\hline 11 & 3.89 & 2.83 & 2.97 & 3.23 & 2.86 & 2.80 & 2.83 & 3.06 \\
\hline 12 & 3.74 & 2.37 & 3.54 & 3.74 & 2.77 & 3.57 & 3.11 & 3.27 \\
\hline 13 & 3.89 & 3.40 & 3.26 & 3.29 & 3.29 & 2.97 & 2.49 & 3.22 \\
\hline 14 & 4.11 & 3.97 & 4.86 & 4.46 & 4.51 & 4.34 & 4.23 & 4.36 \\
\hline 15 & 3.40 & 1.91 & 2.60 & 2.66 & 2.74 & 2.60 & 2.26 & 2.60 \\
\hline 16 & 4.26 & 3.29 & 3.86 & 4.11 & 3.74 & 3.66 & 3.80 & 3.82 \\
\hline 17 & 3.74 & 2.86 & 3.49 & 4.00 & 3.71 & 3.69 & 3.29 & 3.54 \\
\hline 18 & 3.57 & 3.00 & 3.66 & 4.14 & 3.66 & 3.46 & 3.43 & 3.56 \\
\hline 19 & 4.03 & 2.63 & 3.77 & 3.91 & 3.06 & 3.66 & 3.31 & 3.48 \\
\hline 20 & 3.74 & 2.57 & 2.51 & 2.89 & 2.86 & 2.74 & 2.49 & 2.83 \\
\hline 21 & 3.66 & 2.60 & 2.71 & 2.86 & 3.06 & 2.54 & 2.63 & 2.87 \\
\hline 22 & 3.49 & 2.60 & 3.20 & 3.46 & 3.51 & 2.71 & 2.94 & 3.13 \\
\hline 23 & 3.49 & 2.57 & 3.26 & 3.60 & 3.80 & 3.17 & 3.03 & 3.27 \\
\hline 24 & 3.60 & 3.17 & 3.43 & 3.80 & 3.97 & 3.40 & 3.09 & 3.49 \\
\hline 25 & 3.91 & 3.11 & 3.63 & 3.57 & 3.40 & 3.23 & 3.20 & 3.44 \\
\hline 26 & 3.71 & 3.23 & 3.83 & 4.09 & 4.00 & 3.54 & 3.54 & 3.71 \\
\hline 27 & 3.54 & 2.66 & 3.49 & 3.94 & 4.03 & 3.54 & 3.60 & 3.54 \\
\hline 28 & 4.06 & 3.83 & 4.17 & 4.23 & 4.26 & 4.14 & 4.06 & 4.11 \\
\hline 29 & 3.94 & 4.29 & 4.29 & 4.31 & 4.40 & 4.09 & 4.34 & 4.24 \\
\hline 30 & 4.49 & 4.09 & 3.97 & 4.43 & 4.40 & 3.80 & 3.83 & 4.14 \\
\hline
\end{tabular}

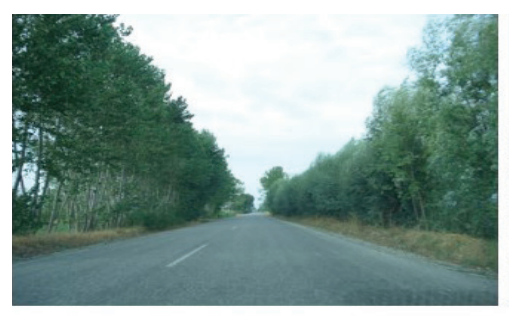

6

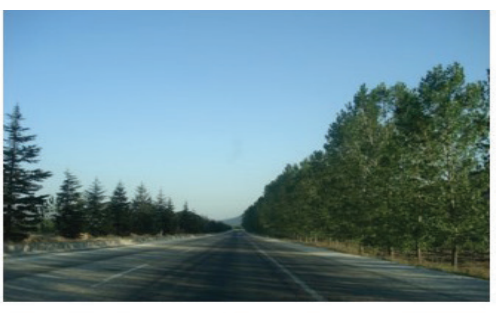

14

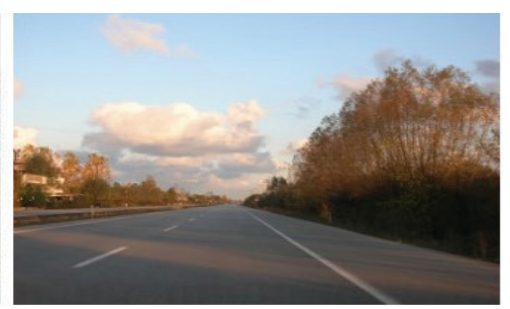

28

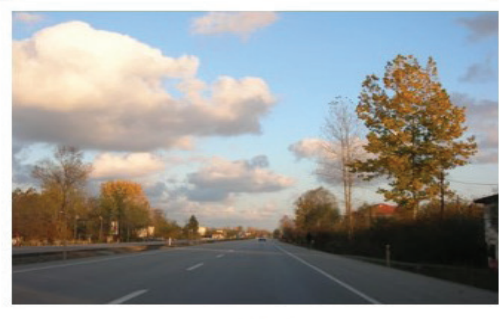

29

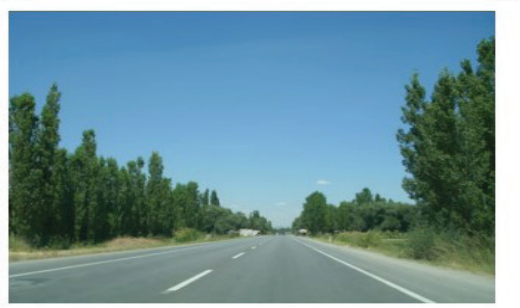

30

Figure 3- High-rated photos 


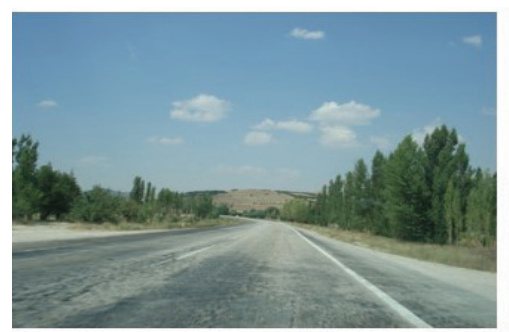

2

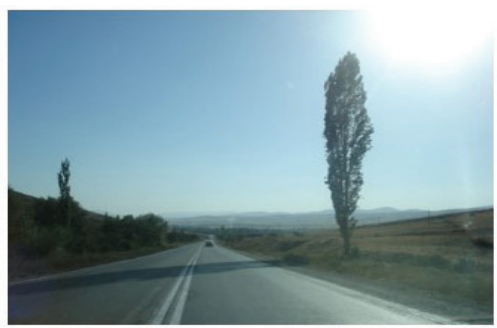

12

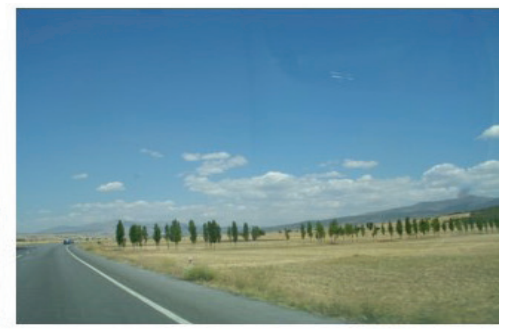

15

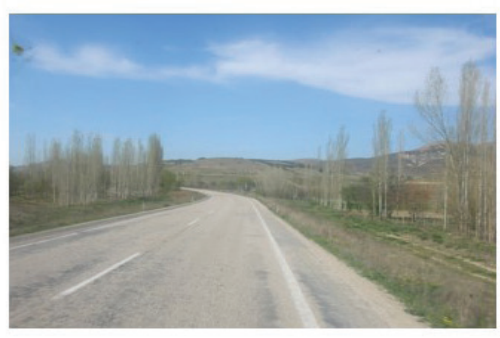

20

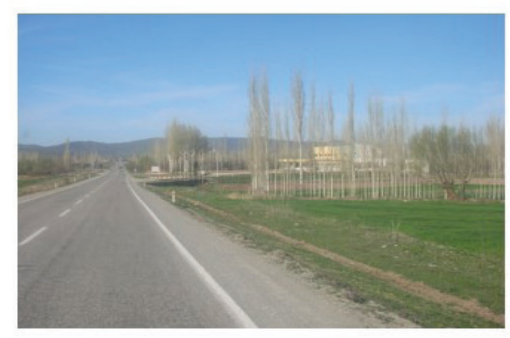

21

Figure 4- Low-rated photos

Table 3- Correlation analysis between visual values and adjective pairs

\begin{tabular}{lccccccc}
\hline & Natural & Varied & Impressive & Eye-Catching & Harmonious & Interesting & Exciting \\
\hline Visual preferences & $0.25^{* *}$ & $0.31^{* *}$ & $0.58^{* *}$ & $0.50^{* *}$ & $0.52^{* *}$ & $0.55^{* *}$ & $0.59^{* *}$ \\
Visual quality levels & -0.02 & -0.02 & $-0.16^{* *}$ & $-0.13^{* *}$ & $-0.12^{* *}$ & $-0.18^{* *}$ & $-0.16^{* *}$ \\
\hline
\end{tabular}

**, correlation significant at the 0.01 level; *, correlation significant at the 0.05 level

Accordingly, increasing age positively impacted the visual preference, while increase in the level of education adversely affected it. Moreover, the visual quality of the poplar plantings was observed to be related to age and gender (Table 4). As seen in Table 5 , there was no relationship between descriptor groups and demographic features.

Table 4- Correlation analysis between visual values and demographic features

\begin{tabular}{lcc}
\hline & Visual preferences & Visual quality levels \\
\hline Age & $0.14^{* *}$ & $0.15^{* *}$ \\
Gender & $-0.07^{*}$ & $0.15^{* *}$ \\
Education & $-0.07^{*}$ & -0.02 \\
Work & $0.06^{*}$ & -0.06 \\
\hline
\end{tabular}

**, correlation significant at the 0.01 level; *, correlation significant at the 0.05 level
Table 5- Correlation analysis between adjective pairs and demographic features

\begin{tabular}{llccc}
\hline & Age & Gender & Education & Work \\
\hline Natural & $0.07^{*}$ & $0.19^{* *}$ & 0.01 & 0.02 \\
Varied & 0.04 & 0.02 & 0.01 & -0.04 \\
Impressive & 0.05 & -0.02 & -0.05 & $0.12^{* *}$ \\
Eye-catching & $0.15^{* *}$ & 0.01 & $0.10^{* *}$ & 0.02 \\
Harmonious & $0.10^{* *}$ & 0.03 & $0.07^{*}$ & -0.05 \\
Interesting & $0.09^{* *}$ & $-0.10^{* *}$ & 0.00 & $0.10^{* *}$ \\
Exciting & $0.11^{*}$ & -0.04 & 0.04 & 0.05 \\
\hline
\end{tabular}

**, correlation significant at the 0.01 level; *, correlation significant at the 0.05 level

3.3. Clustering the roadside environments based on visual attributes

In order to identify landscape visual perception values, the descriptors were divided into groups 
according to the results of the cluster analysis. The first group included natural, eye-catching and harmonious, whereas the second one was comprised of varied, impressive, interesting and exciting (Figure 5).

The photos were then divided into three different groups (Figure 6) according to their visual and landscape perception values. Three homogeneous groups/clusters were obtained from the viewpoints of

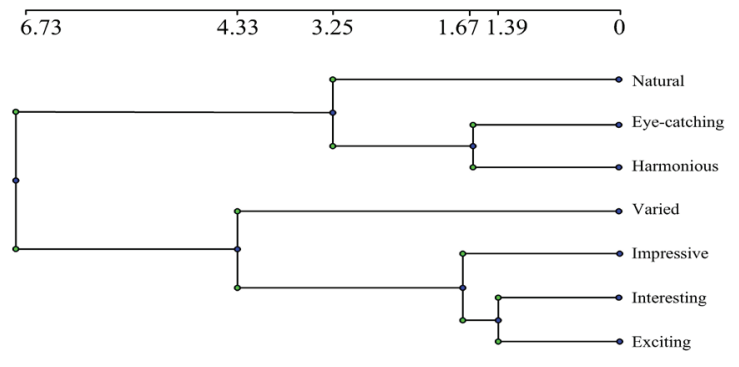

Figure 5- Cluster analysis of adjective pairs
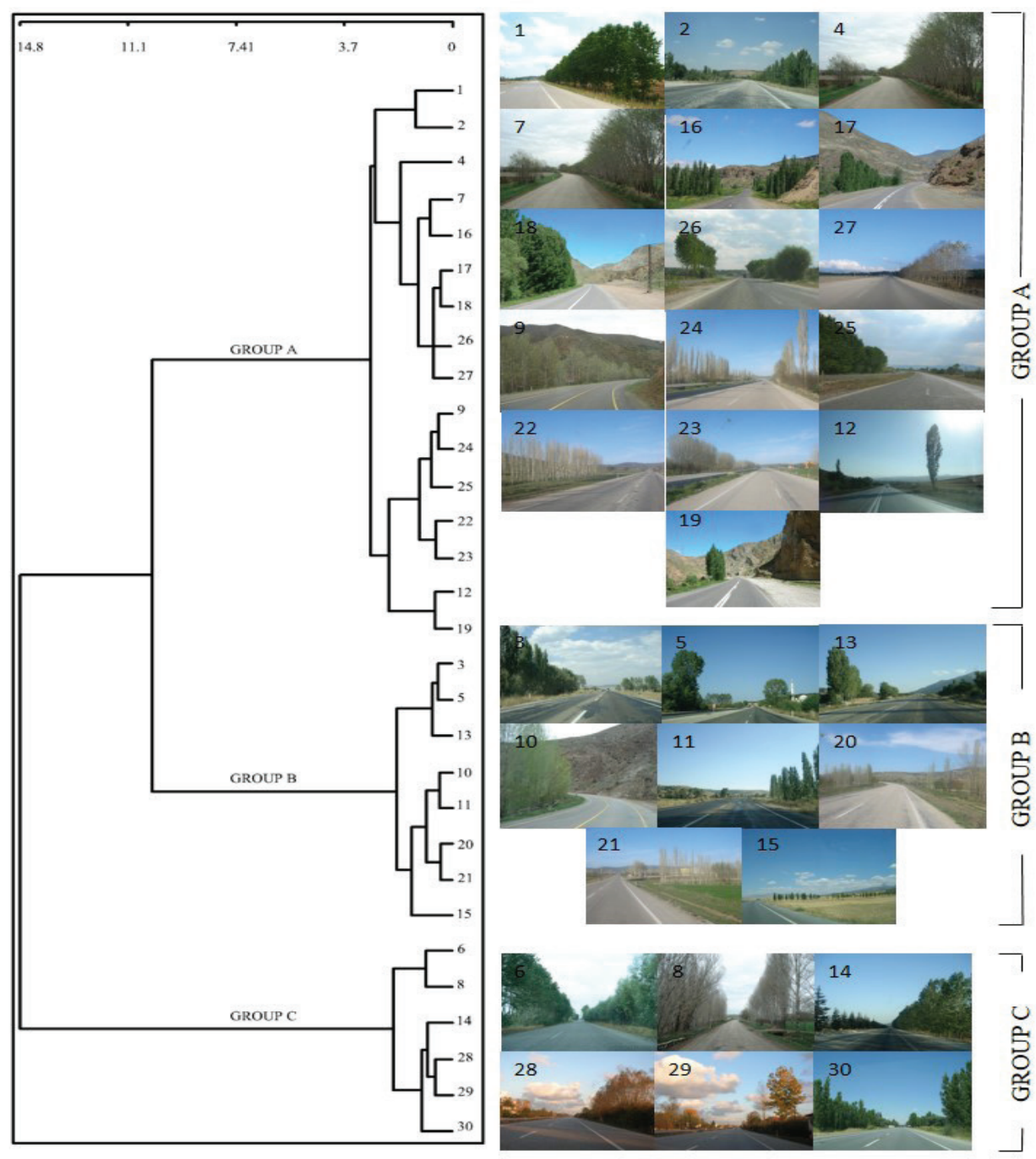

Figure 6- Cluster analysis of photos

Tarım Bilimleri Dergisi - Journal of Agricultural Sciences $\quad 24(2018)$ 185-198 
35 participants measured on the basis of categorical variables for the 30 photographs.

According to the cluster analysis results; Group A included 1, 2, 4, 7, 9, 12, 16, 17, 18, 19, 22, 23, 24, 25, 26 and 27 (moderate grouping, moderate density, summer-autumn), Group B included 3, 5, 10, 11, 13, 15, 20 and 21 (less grouping (solitary), low density, autumn-winter) and Group $\mathrm{C}$ included $6,8,14,28,29$ and 30 (greater grouping effect (more poplar in the composition), more plant and leaf density, spring-summer).

These clusters, especially the seasonal status of the poplar compositions, their density, and the case of a single species or groupings of trees, were observed to be effective.

We used discriminant analysis to test the accuracy of the resulting clusters in the cluster analysis. These three groups are shown in the discriminant function graph in Figure 7. An examination of Table 6 indicates the groups were correctly classified, with the high probability value of $93.4 \%$. Thus, a consistent selection of visual and sensory parameters according to the populus viewpoint was demonstrated.

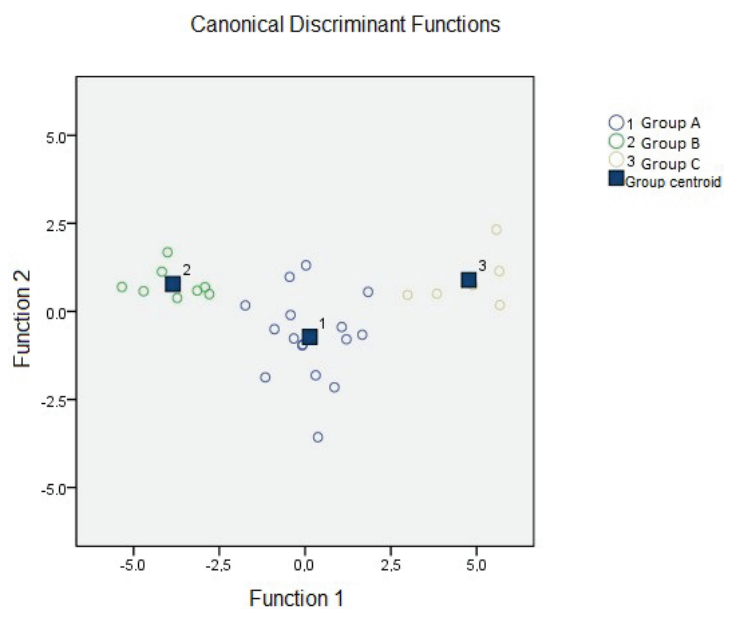

Figure 7- Discriminant analysis graph of the grouped photos

Table 6- Discriminant function analysis showing accuracy

\begin{tabular}{ccccc}
\hline Function & Eigenvalue & \% of Variance & Cumulative \% & Canonical correlation \\
\hline 1 & $9.466^{\mathrm{a}}$ & 93.4 & 93.4 & 0.951 \\
2 & $0.667^{\mathrm{a}}$ & 6.6 & 100.0 & 0.633 \\
\hline
\end{tabular}

\section{Discussion}

There is growing scientific evidence of the importance of the roadside landscape and the visual characteristics along the highways in terms of the perception of those who use the roads. As the landscapes become more interesting and the aesthetic quality of the roadside ambiance increases, relationships between the roadways and their surroundings may be more readily acknowledged (Acar \& Gülez 2002; Cackowski \& Nasar 2003; Froment \& Domon 2006; Dell'Acqua \& Russo 2010). Moreover, the roads and streets in urban spaces together with those in rural areas are known to be important elements of the transportation landscape (Acar \& Günay 2014) and are credited with being new venues for bringing people and plants together
(Pellegrini \& Baudry 2014). Therefore, the aim of this study was to determine visual preferences for the composition of roadside poplar plantings in Turkey. The results have confirmed some significant relationships in the choice of planting poplar as the characteristic species in roadside landscape designs.

According to the findings obtained in this study, the most admired photographs, numbered 6, 14, 28, 29 and 30 have the common features of density and proximity to the road, while photographs 2 , $12,15,20$ and 21 picture remote and sparselyspaced plantings. Indeed, in the studies of Mader \& Neubert-Mader (2004), Wolf (2006) and Fathi \& Masnavi (2014), it is stated that the plants closest to the road are much more appreciated and that the 
increasing number of plants in the composition strengthen the visual impact.

In the assessments, there appears to be an intermediate level of naturalness for virtually all groups of photos. However, in the photographs numbered 2, 8, 16 and 30, where the poplar species are tall and close to the road and the area is effectively rural, the naturalness value is even higher. It is thought that naturalness values are not very high mainly because the trees are not naturally grown, but planted there, whereas the values are not very low because of the recognition factor. Atik et al (2013) stated that commonly recognized vegetation is associated with the feeling of naturalness.

Regarding the taste and visual assessment level of the photos made according to the results of the cluster analysis, in the emergence of the urban-rural relationship of the current groups, the increase in the number of trees and proximity to the road were seen to be effective. Therefore, plant group A was more urban, while group B included the more rural areas; the plantings of group B were sparse, while those of groups $\mathrm{A}$ and $\mathrm{C}$ were denser.

\subsection{Roadside environment and trees as visual landscape elements}

In the results of this study, it was observed that plants are more preferable when used in an effective manner that characterizes the road (Figures 3 and 4). This idea is compatible with environmental psychology studies in the literature because, according to the Gestalt theory, effective environments play a key role in human perception (Gürer 1990; Bell 2004; Güngör 2005). In this study, when the poplars close to the roadside were used in a manner to construct more mass-space and an effective environment, their preference levels rose. Additionally, according to evaluations using semantic descriptors for the relationship between road and plants, being sufficiently varied and eye-catching was important for the roadside environment (Figure 2). However, naturalness was also identified as an important element in the semantic evaluation because the roads in the study belonged to rural landscapes. On the other hand, road-dominated landscapes were less preferred by participants. In the correlation analysis in Table 3, road-dominated poplar plantings were qualified as exciting. According to Kaplan \& Kaplan (1989), exciting is directly related to mysterious, so mysterious roads become exciting and their visual preference is increased. Therefore, in the study, varied, impressive, interesting and exciting were clustered together in one group and natural, eyecatching and harmonious in the other (Figure 5). This result is supported by previous studies (Akbar et al 2003; Clay \& Smidt 2004; Fathi \& Masnavi 2014) in which natural, eye-catching, varied and harmonious were indicated as identifying elements of visual preference for roadside vegetation, just as in this present research.

Serpa \& Muhar (1999) stated that gender along with geographic and social origins affect how plants are perceived. Moreover, the gender, age, habitation and experiences of individuals also affect their visual preferences (Strumse 1996). As shown in the results of the present study, the visual preferences for poplar plantings were also related to age and gender.

Eroğlu et al (2012) reported that the potential of seasonal variations in plant composition affects visual preference positively. As a result of this study, it was also observed that higher values of visual preference were obtained with photograph groups which included much more seasonal variation and autumn coloring.

The types of plant composition are important, whether plants are used singly or in groups and plant density, and seasonal change in the visual perception and assessment of plant composition (Eroğlu \& Acar 2011; Eroğlu et al 2012). In this study, the resulting situation was similar in character, especially with the cluster analysis.

The descriptor groups are significant visual assessment parameters for the explanation of components belonging to the landscape (Osgood et al 1975; Clay \& Smidt 2004; Müderrisoğlu et al 2006; Ode et al 2009; Eroğlu et al 2012; Acar et al 2013). In the present study, the groups of descriptors were also effective in the determination of the value 
of the poplar plantings in the visual landscape. The areas of high landscape value were those consisting of groups with intensive plantings and vegetation.

\subsection{Poplar trees as tools for roadside greenery}

Although roadside planting had its beginnings in ancient times, this type of planting activity took off during the Renaissance in Europe, where it continued to flourishing in the $17^{\text {th }}$ Century and reached its peak in the $18^{\text {th }}$ Century (Mader $\&$ Neubert-Mader 2004). In Turkey, roadside planting has been rapidly developing since the establishment of the Republic. Roadside poplar planting has been widely used by private individuals and public institutions up to the present day because of the ease in planting and the cheap maintenance costs of the poplar species.

According to Yilmaz (2012), poplar has many ecological and economic advantages. In addition to contributing to the visual enhancement of the rural Turkish landscape, the versatile poplar species should be given a place in planting design projects along with other native Turkish plant species. In this work, it can be seen that poplar exhibits one of the essential characteristics of natural landscape design by providing the important feature of linking rural and urban environments. Moreover, all these poplar plantings along roads in the cities and in the countryside represent the Anatolian cultural heritage of the people living there (Y1lmaz 2012).

\section{Conclusions}

According to the findings of this study, poplars are important roadside trees for their rural-urban linking and ecological contributions as well as for their demonstrated natural effect and their visual diversity, effectiveness, and suppleness. The following conclusions were reached regarding a number of roadside poplar plantings in Turkey. Proximity to the road corridor and abundance of trees in the composition increase the level of visual appreciation of the roadside poplar species. As a commonly recognized species in rural areas, the roadside poplar is perceived as more natural. Roadside vegetation affects the visual value of landscape perception. In addition, this effect can vary according to demographic features. The richness, density and variety of roadside vegetation increase the visual landscape value and quality. As vegetation groups are found nearer to roadsides, visual landscape perception, quality and preference values rise. Poplars planted on roadsides should not create traffic hazards that endanger human safety. In determining visual preferences, the appreciation of roadside poplar plantings rose with the increasing age of the participants, while increasing educational levels affected appreciation in a negative way. In this case, the higher the education level, the more selective the participants were in their visual preferences. Interest and excitement were the most important factors in determining the visual preferences of the roadside poplar plantings. Poplar planting schemes and their seasonal variations affect visual preferences.

Thus, it was concluded that vegetation groups, especially roadside poplar plantings, have significant value in the visual landscape. This is particularly true of roadside vegetation including poplar plantings, which create an ecological corridor connecting the rural and urban landscapes.

\section{References}

Abonyi J \& Feil B (2007). Cluster Analysis for Data Mining and System Identification. $1^{\text {st }}$ ed. Birkhauser Verlag AG, Berlin

Acar C \& Gülez S (2002). Ecological and visual structure along Trabzon-Rize coastal highway in Turkey. Journal of Balkan Ecology 5(2): 119-133

Acar C \& Günay K (2014). Kentsel ulaşım peyzajı üzerine tasarım ve planlama önerileri. In: Şehircilik ve Ulaşım Planlamasi Sempozyumu, 26 Eylül 2014, Trabzon Bildirler Kitapçığı, pp. 71-88

Acar C, Kurdoğlu B Ç, Kurdoğlu O \& Acar H (2006). Public preferences for visual quality and management in the Kackar Mountains National Park (Turkey). International Journal of Sustainable Development \& World Ecology 13: 499-512

Acar C, Akkaya H, Ayhan N \& Eroğlu E (2008). A visual assessment of coastline landscape design in eastern black sea region of Turkey: A case study of 
Vakfikebir. In: Abstract Book of MARENPOL 2008, Trabzon, pp. 38

Acar H, Eroğlu E \& Acar C (2013). Landscape values of rocky habitats in urban and semi-urban context of Turkey: A study of Tokat city. Journal of Food Agriculture \& Environment 11(2): 1200-1211

Akbar K F, Hale W \& Headley A D (2003). Assessment of scenic beauty of the roadside vegetation in northern England. Landscape and Urban Planning 63: 139144

Atik M, Karagüzel O \& Durak A (2013). Bitkisel tasarımda doğal bitki türleri ve Antalya örneğinde kullanım potansiyeli. In: V. Süs Bitkileri Kongresi Bildiriler Kitabı 1, 6-9 May, Yalova, pp. 117-125

Avşar M D \& Ok T (2010). Using poplars (Populus spp. L.) in urban afforestation: Kahramanmaraş sample. Süleyman Demirel University, Journal of Faculty of Forestry 2: 127-135

Bell S (2004). Elements of Visual Design in the Landscape, $2^{\text {nd }}$ ed. Spon Press, London and New York

Brown T C \& Daniel T C (1990). Scaling of ratings: Concepts and methods. Research Paper RM-293. Fort Collins, CO: US Department of Agriculture, Forest Service, Rocky Mountain Forest and Range Experiment Station, 22

Bulut Z \& Yilmaz H (2008). Determination of landscape beauties through visual quality assessment method: A case study for Kemaliye (Erzincan/Turkey). Environmental Monitoring and Assesment 141(1-3): 121-129

Cackowski J M \& Nasar J L (2003). The restorative effects of roadside vegetation: implications for automobile driver anger and frustration. Environment and Behaviour 35(6): 736-751

Clay G R \& Daniel T C (2000). Scenic landscape assessment: the effects of land management jurisdiction on public perception of scenic beauty. Landscape and Urban Planning 49(1-2): 1-13

Clay G R \& Smidt R K (2004). Assessing the validity and reliability of descriptor variables used in scenic highway analysis. Landscape and Urban Planning 66(4): 239-255

Çepel N (1998). Peyzaj Ekolojisi. İstanbul University Faculty of Forestry Publications: 3510, İstanbul

Daniel T C \& Vining J (1983). Methodological issues in the assessment of landscape quality. In: I Altman \& F Wohlwill (Eds), Behavior and the Natural Environment, Plenum Press, New York
Dell'Acqua G \& Russo F (2010). Descriptors in scenic highway analysis: A test study along Italian road corridors. International Journal for Traffic and Transport Engineering 1(2): 73-88

Demir Z \& Eroğlu E (2015). Visual effects of some roadside deciduous trees on road users. In: Abstract Book of Macodesu 2015, Trabzon, pp.140

Dirik H (2008). Plantasyon (Bitkilendirme ve Dikim) Teknikleri. İstanbul University Faculty of Forestry Publications: 4729, İstanbul

Eroğlu E \& Acar C (2011). Visual landscape character of oriental spruce (Picea orientalis (L.) link.) mountain forests in Turkey. Journal of Environmental Engineering and Landscape Management 19(3): 189197

Eroğlu E, Müderrisoğlu H \& Kesim G A (2012). The effect of seasonal change of plants compositions on visual perception. Journal of Environmental Engineering and Landscape Management 20(3): 199-205

Everitt B S, Landau S \& Leese M (2001). Cluster Analysis. Arnold/Hodder Headline Group, London

Fathi M \& Masnavi M R (2014). Assessing environmental aesthetics of roadside vegetation and scenic beauty of highway landscape: Preferences and perception of motorists. International Journal of Environmental Ressearch 8(4): 941-952

Froment J \& Domon G (2006). Viewer appreciation of highway landscapes: The contribution of ecologically managed embankments in Quebec, Canada. Landscape and Urban Planning 78(1-2): 14-32

Görcelioğlu E (2002). Peyzaj Onarım Tekniği. İstanbul University Faculty of Forestry Publications: 4351, İstanbul

Güngör İ H (2005). Görsel Sanatlar ve Mimarlık için Temel Tasar. Esen Ofset, İstanbul

Gürer L (1990). Temel Tasarım. Teknik Üniversite Matbaas1, İstanbul

Kalaycı Ş (2010). SPSS Uygulamalı Çok Değişkenli İstatistik Teknikleri. Asil Yayınları Dağıtım, Ankara

Kalıpsız A (1981). İstatistiksel Yöntemler. İ.Ü. Orman Fakültesi Yayınları: 2837-294, İstanbul

Kaplan R \& Kaplan S (1989). The Experience of Nature: A Psychological Perspective. Cambridge University Press, Cambridge

Mader G \& Neubert-Mader L (2004). BäumeGestaltungsmittel in Garten, Landschaft und Städtebau. Komet Cologne, Germany 
Müderrisoğlu H \& Eroğlu E (2006). Differences in visual perception of some coniferous trees under snow load. Süleyman Demirel University, Journal of Faculty of Forestry 1: 136-146

Müderrisoğlu H, Eroğlu E, Ak K \& Aydın Ş Ö (2006). Visual perception of tree form. Building and Environment 41: 796-806

Ode A, Fry G, Tveit M S, Messager P \& Miller D (2009). Indicators of perceived naturalness as drivers of landscape preference. Journal of Environmental Management 90(1): 375-383

Osgood C E, Suci G J \& Tannenbaum P H (1957). The Measurement of Meaning. The University of Illinois Press, Urbana IL

Osgood C E, May W H \& Miron M S (1975). Crosscultural Universals of Affective Meaning. University of Illinois Press, Urbana IL

Özgen Y (1984). Doğu Karadeniz bölgesinde Ordu-Rize arası kıyı yolunun peyzaj özellikleri, peyzaj mimarlığ1 açısından ortaya koyduğu sorunlar ve çözümü üzerine bir araştırma (Doktora Tezi Özeti). İstanbul Üniversitesi Orman Fakültesi Dergisi 34 (2): 1-3

Pellegrini P \& Baudry S (2014). Streets as new places to bring together both humans and plants: Examples from Paris and Montpellier (France). Social \& Cultural Geography 15(8): 871-900

Serpa A \& Muhar A (1999). Effects of plant size, texture and colour on spatial perception in public green areas-a cross-cultural study. Landscape and Urban Planning 36(1): 19-25

Spooner P G \& Lisa S (2009). Effects of road age on the structure of roadside vegetation in south-eastern Australia. Agriculture, Ecosystems \& Environment 129: $57-64$
Strumse E (1996). Demographic differences in the visual preferences for agrarian landscapes in western Norway. Journal of Environmental Psychology 16(1): $17-31$

Todorova A, Asakawa S \& Aikoh T (2004). Preferences for and attitudes towards street flowers and trees in Sapporo, Japan. Landscape and Urban Planning 69: 403-416

Trowbridge P J \& Bassuk N L (2004). Trees in the Urban Landscape Site Assessment Design and Installation. Wiley, ISBN 0-471-39246-4, USA

Ürgenç S İ (1998). Ağaç ve Süs Bitkileri Fidanlık ve Yetiştirme Tekniği, 2. Baskı, İstanbul Üniversitesi Orman Fakültesi Yayınları, 3395-442, İstanbul

Weber F, Kowarik I \& Saumel I (2014). A walk on the wild side: Perceptions of roadside vegetation beyond trees. Urban Forestry \& Urban Greening 13(2): 205212

Wolf K L (2006). Assessing Public Response to Freeway Roadsides. Transportation Research Record: Journal of the Transportation Research Board No. 1984. National Academies, Washington DC, pp. 102-111

Yaltırık F (1993). Dendroloji Ders Kitabı II-Angiospermae (Kapal1 Tohumlular), 2 $2^{\text {nd }}$ ed. İstanbul University Faculty of Forestry Publications, 3767-420, İstanbul

Yavuzşefik Y \& Uzun O (2005). Peyzaj Onarım Tekniği, Düzce

Y1lmaz E (2008). Okaliptüsün su tüketimi ile kent ve yol ağacı olarak değeri hakkında rapor. Journal of $D O A$ 14: 1-31

Y1lmaz H(2012). Kırsal peyzaj karakterinin vazgeçilmezi; Kavaklar. Plant Dergisi 7: 64-66 